\title{
Influence of Prohexadione Calcium on Sweetpotato Growth and Storage Root Yield
}

\author{
Victor N. Njiti, Qun Xia, Leonna S. Tyler, Lakeisha D. Stewart, \\ Antione T. Tenner, Chunquan Zhang, Dovi Alipoe, \\ Franklin Chukwuma, and Ming Gao \\ Department of Agriculture, Alcorn State University, 1000 ASU Drive, Alcorn \\ State, MS 39096
}

Additional index words. sink, source, biomass, plant growth inhibitor, storage root, assimilates

\begin{abstract}
Excessive vine growth in sweetpotato has been associated with lower storage root yield. Prohexadione-calcium (Pro-Ca), a plant growth retardant, has been used to reduce vegetative growth and increase harvest efficiency and yield in many fruit and row crops. The influence of Pro-Ca on sweetpotato (Ipomoea batatas Lam.) vegetative growth and storage root yield was evaluated in this study. In 2010 and 2011, the sweetpotato cvs. Beauregard, Porto Rico, O' Henry, and SC1149-19 were sprayed with 0 and $810 \mathrm{mg}$ a.i./L Pro-Ca in a split plot randomized complete block. Each plot received two sprays, the first at 2 weeks after transplanting and the second at 6 weeks after transplanting. When averaged across cultivars, Pro-Ca significantly $(P \leq 0.05)$ reduced vine length and vine yield and increased total root yield compared with the control. There was no significant Pro-Ca $\times$ cultivar interaction on any trait. Total biomass was not significantly $(P \leq 0.05)$ different between Pro-Ca-treated and control plants. However, the treated plants had more total root yield, whereas the control plants had more vine yield, suggesting that ProCa treatment affected the distribution of assimilates. Data from this study suggested that it may be possible to use Pro-Ca to manipulate the source-sink relationship for higher storage root yield in sweetpotato.
\end{abstract}

The sweetpotato is among the top seven main crops in the world with more than 130 million tons produced each year (All-aboutsweet-potatoes.com, 2011). It grows well in poor soils and harsh environments (CIP, 1999) and, depending on the cultivar and growth conditions such as soil nitrogen, soil moisture, and photoperiod, will produce a huge amount of interlocking vines (Somasundaram and Santhosh Mithra, 2008). Uncontrolled vegetative growth presents multiple problems of great economic importance, including encroachment that can increase harvest cost and reduce harvest efficiency (Smith and Wright, 1994) and increase photoassimilate sink capacity of non-economical (vegetative) plant parts (Renter and Stassen, 1998). Although several plant growth inhibitors have been found to be effective in controlling vegetative growth, there are few without health and environmental concerns (Miller, 2002).

Prohexadione-calcium (calcium 3-oxido5-oxo-4-propionylcyclohex-3-enecarboxylate) belongs to a new class of plant growth retardants called acylcyclohexanetriones (Nakayama

\footnotetext{
Received for publication 29 Aug. 2012. Accepted for publication 15 Oct. 2012.

Thanks to the USDA/NIFA for providing the funds (Grant Numbers 2010-38821-21478 and 2009-38863-20054) necessary to conduct this study. Thanks to all the students who participated in this work.

${ }^{1}$ To whom reprint requests should be addressed; e-mailvicnji@alcorn.edu.
}

et al., 1992; Rademacher, 2000). Pro-Ca is believed to act by competing with the natural cosubstrate, 2-oxoglutarate, at the active site of dioxygenases, which catalyzes the later stages of the biosynthesis of gibberellins (GA) (Rademacher, 2000). Pro-Ca inhibits the conversion of biologically inactive GA20 into biologically active GA1, involved in shoot elongation in many plant species (Nakayama et al., 1991, 1992; Rademacher, 2000). Unlike other plant growth retardants, Pro-Ca is only taken up by the green tissues, breaks down shortly without leaving a residual effect, and is registered for use in horticulture crops (Rademacher, 2000).

Pro-Ca has been used successfully to reduce labor cost in many fruit and row crops including apples (Evans et al., 1999; Miller, 2002), pears (Smith et al., 2005), and peanuts (Beam et al., 2002; Jordan et al., 2001). In fruit trees, the reduction in labor cost was achieved through reduction in pruning time. In peanuts, the reduced labor cost was attributed to increased harvesting efficiency (Beam et al., 2002).

Vegetative growth reduction in fruit trees has been shown to reduce competition between vegetative and reproductive sinks (Hicklenton, 1990; Williams, 1988). Manipulation of sinks capacity may enhance sweetpotato yield through assimilates repartitioning. The sweetpotato is a storage root and a major carbohydrate sink. Suppressing the growth of vegetative material may have the potential to reduce the aboveground sink capacity thereby sending more assimilates to roots
(Williams, 1988). Pro-Ca application was found to increase the chlorophyll contents of apple and pear leaves, resulting in a net increase in photosynthesis (Sabatini et al., 2003). If Pro-Ca has the same effect in sweetpotato, it will strengthen the source capacity and increase the amount of assimilate available to grow the storage root.

Pro-Ca has been used to reduce pruning time in apple (Miller, 2002), increase fruit yield (Renter and Stassen, 1998), and increase harvesting efficiency (Beam et al., 2002). It is expected that using Pro-Ca to limit vine growth in sweetpotato may redirect more photoassimilates down to form and/or grow storage roots, resulting in increased yield. This study examined the influence of Pro-Ca on sweetpotato vegetative growth and storage root yield among four cultivars.

\section{Materials and Methods}

Two experiments were conducted in a field on the campus of Alcorn State University (lat. $31.8769^{\circ} \mathrm{N}$, long. $91.1411^{\circ} \mathrm{W}$ ) located in Lorman, southwest MS, in 2010 and 2011 to determine the effects of Pro-Ca (Apogee $^{\circledR}$; BASF Corp., Research Triangle Park, NC) on sweetpotato vegetative growth and storage root yield among four cultivars. The experiments were planted on Memphis silt loam soil (Fine-silty, mixed, active, thermic Typic Hapludalfs). The experiments were planted on 1 and 6 June for 2010 and 2011, respectively. The two experiments were conducted in different sections of the same field having the same soil type.

Plant material. Four sweetpotato cultivars, three of which are commonly grown in Mississippi, were used in this study. 'Beauregard', a bush vine-type sweetpotato (Rolston et al., 1987), matures in $90 \mathrm{~d}$ and has excellent storage root yield; 'Porto Rico', a compact bush vine-type sweetpotato with small runners (Nielson and Pope, 1960), matures in $110 \mathrm{~d}$ and has good storage root yield; 'O'Henry', a white-flesh variant mutant of 'Beauregard' with the same growth characteristics as 'Beauregard' but matures in $100 \mathrm{~d}$ and has good storage root yield; and 'SC1149-19', a prolific vine producer with very low storage root yield was developed in South Carolina.

Experimental design and plot management. The experiments were conducted in a split plot, randomized complete block design with two replications. Pro-Ca treatments $(0$ and $810 \mathrm{mg}$ a.i./L) were the main plots and cultivars were the subplots. Pro-Ca-treated and control plots were separated by a $3-\mathrm{m}$ buffer zone to prevent drift during spraying. Sweetpotato was transplanted to conventionally prepared raised beds at a rate of 10 plants per row with $0.45 \mathrm{~m}$ between plants within the row and $1.06 \mathrm{~m}$ between rows. Each plot consisted of two rows. Before plowing the field, glyphosate was applied to burn down all weeds. Post-transplant weed control was accomplished by hand-hoeing. Soil nutrient amendments were based on Mississippi 
State University soil test recommendations. Drip irrigation was used as needed during the first 4 weeks after transplanting.

Treatments. Treatment plots were sprayed with Pro-Ca at a concentration of $810 \mathrm{mg}$ a.i./ $\mathrm{L}$ or a rate of $140 \mathrm{~g}$ a.i./ha (Beam et al., 2002; Njiti et al., 2012) mixed with $1 \mathrm{~mL} \cdot \mathrm{L}^{-1}$ of crop oil concentrate (Loveland Products, Inc., Greeley, $\mathrm{CO}$ ) and $1 \mathrm{~mL} \cdot \mathrm{L}^{-1}$ urea ammonium nitrate (CF Industries Holdings, Inc., Deerfield, IL) using a handheld Premier Pro compressed air sprayer (Chaplin Manufacturing Inc., Batavia, NY). Plants were sprayed until runoff. The control plots were sprayed with water mixed with $1 \mathrm{~mL} \cdot \mathrm{L}^{-1}$ of crop oil concentrate and $1 \mathrm{~mL} \cdot \mathrm{L}^{-1}$ urea ammonium nitrate. Each plot received two sprays, the first of which was 2 weeks after transplanting and the second was 6 weeks after transplanting. In 2010, the first spray was on 15 June and the second was on 15 July and in 2011, the first spray was on 22 June and the second was on 22 July.

Data collection. Experiments were harvested 95 and $107 \mathrm{~d}$ after transplanting in 2010 and 2011, respectively. The first five plants of each of two rows per subplot (10 plants per subplot) were dug up with a shovel, taking care not to damage the roots. Roots were separated from the vines. Roots and vines were weighed (on a fresh weight basis) using a floor electronic platform scale with a capacity of $300 \mathrm{~kg}$ (Global Equipment Company Inc., Port Washington, NY). Vine and root weights were converted to yields (tons/ha) using appropriated conversion factors. Adventitious root with visible localized swelling of $0.5 \mathrm{~cm}$ at its widest section was considered a storage root (Smith and Villordon, 2012). Total root yield $=$ pencil (lignified, long, stringy) roots + storage roots. Marketable roots consisted of storage roots with diameter of $2.54 \mathrm{~cm}$ or larger and length of $5.8 \mathrm{~cm}$ or longer that were free of severe misshape and pest damage (USDA, 2005). Total biomass $=$ total root yield + vine yield. The number of storage roots from each subplot was recorded and storage roots/plant was calculated. Vine length was determined by measuring the length of the main vine from each of three randomly selected plants from each subplot using a retractable steel tape measure (The Perfect Measuring Tape ${ }^{\circledR}$ Company, Toledo, $\mathrm{OH})$.

Data analysis. Data were analyzed using the SAS statistical program (SAS Institute, 1985). The General Linear Model procedure was used to test treatments and interaction effects. Means were compared by least significant difference at the $5 \%$ probability level (Gomez and Gomez, 1984). Charts were constructed using Excel 2007 (Microsoft Inc., Redmond, WA). In this study, Pro-Ca and cultivar were considered fixed effects, whereas experiment and replication were considered random effects.

\section{Results}

Analysis of variance revealed that there were no significant differences between experiments in vine length, vine yield, total root yield, total biomass, and marketable yield (Table 1). However, there was a significant $(P \leq 0.05)$ difference between experiments in storage roots/plant. There was a significant $(P \leq 0.05)$ effect of Pro-Ca on all traits measured in this study (Table 1 ). This effect was not influenced by experiment or cultivar as indicated by the lack of significant $(P \leq$ 0.05 ) experiment $\times$ Pro-Ca and Pro-Ca $\times$ cultivar interactions (Table 1). Hence, the effect of Pro-Ca on vine length, total root yield, and vine yield was averaged over experiments (Fig. 1-2). There were no significant effects of cultivar on vine length, vine yield, or storage roots/plant (Table 1). However, there was a significant $(P \leq 0.05)$ effect of cultivar on total root, marketable root, and total biomass yields (Table 1). There was a significant effect of cultivar and experiment $X$ cultivar interaction (Table 1) on storage roots/ plant. Hence, results for storage roots/plant were presented by cultivar and experiment (Fig. 3).

The application of Pro-Ca on sweetpotato in this study consistently reduced vine length relative to the control (Fig. 1). Reduction in vine length was consistent across all cultivars. Application of Pro-Ca caused reductions in vine yield relative to the control (Fig. 2). The reductions were significant $(P \leq 0.05)$ when averaged across experiments within two of four cultivars (Fig. 2). There were no significant differences among cultivars in vine yield both in the absence and presence of Pro-Ca treatment (Fig. 2). Total root yield, averaged across cultivars, was significantly $(P \leq 0.05)$ higher for Pro-Ca treated compared with the control plants (Fig. 2). This significant yield effect was also found within all cultivars, except 'SC1149-19' (Fig. 2). 'SC1149-19' had significantly $(P \leq 0.05)$ lower total root yield than the other three cultivars that did not differ from each other both in the presence and absence of Pro-Ca (Fig. 2). Pro-Ca application did not appear to influence marketable root yield, because marketable yield as a percentage of total root yield was 87 and 88 for treated and control plants, respectively (Fig. 2). Pro-Ca application did not influence storage roots/plant (Fig. 3). A significant $(P \leq 0.05)$ effect of Pro-Ca on storage roots/plant was only detected within the cv. Porto Rico in the 2011 experiment. There was a significant $(P \leq 0.05)$ cultivar $\times$ experiment interaction for storage roots/plant (Table 1).

\section{Discussion}

Reductions in vine length and vine yield of Pro-Ca-treated plants, relative to the controls that were observed in this study, were consistent with previous reports indicating that Pro-Ca can reduce vegetative growth by up to $60 \%$ in fruit trees and other crops including apples (Evans et al., 1999; Norelli and Miller, 2004), pears (Smith et al., 2005; Rademacher et al., 2004), and peanuts (Beam et al., 2002; Jordan et al., 2001). Reduction in vine length was a result of reduction in internode length (Njiti et al., 2012) believed to be a result of the inhibition of growth specific gibberellins that are primarily responsible for shoot elongation (Nakayama et al., 1991, 1992; Rademacher, 2000). The lack of a significant Pro-Ca $\times$ cultivar interaction for vegetative growth parameters in this study contradicted previous reports indicating that the growth suppression ability of Pro-Ca is cultivar-dependent (Miller, 2002). This may have been an indication of limited genetic diversity and variation in vigor among the cultivars.

Although Pro-Ca treatment resulted in significant reductions in both vine length and vine yield compared with the control, correlation analysis between vine length and vine yield indicated that reduction in vine length only accounted for $\approx 47 \%(r=0.69)$ of variation in vine yield. Previous reports indicate that although Pro-Ca treatment reduced vine length, it also increased vine diameter and leaf thickness relative to the control (Kofidis et al., 2008; Njiti et al., 2012). This may have some mitigating effects on vine yield loss associated with vine length reduction resulting from Pro-Ca treatment. It is unlikely that vines/plant influenced vine yield because previous reports indicate no significant difference in the number of branches between Pro-Ca-treated and control plants (Kofidis et al., 2008; Njiti et al., 2012).

In this study, Pro-Ca-treated plants experienced vegetative growth reduction and had higher total root yield. Yield enhancement

Table 1. Significance of mean squares from combined analysis of variance; two experiments (2010 and 2011); four cultivars (Beauregard, Porto Rico, O'Henry, and SC1149-19), and two prohexadionecalcium (Pro-Ca) levels (treated and control).

\begin{tabular}{lccccccc}
\hline Sources of variation & df & $\begin{array}{c}\text { Vine } \\
\text { length }\end{array}$ & $\begin{array}{c}\text { Vine } \\
\text { yield }\end{array}$ & $\begin{array}{c}\text { Total } \\
\text { root yield }\end{array}$ & $\begin{array}{c}\text { Storage } \\
\text { root/plant }\end{array}$ & $\begin{array}{c}\text { Total } \\
\text { biomass }\end{array}$ & $\begin{array}{c}\text { Marketable } \\
\text { root yield }\end{array}$ \\
\hline Experiment (E) & 1 & NS & NS & NS & $* *$ & NS & NS \\
Pro-Ca (P) & 1 & $* * *$ & $* * *$ & $* * *$ & $* * *$ & $*$ & $* *$ \\
E $\times$ P & 1 & NS & NS & NS & NS & NS & NS \\
Cultivar (C) & 3 & NS & NS & $* * *$ & NS & $* *$ & $* * *$ \\
E $\times$ C & 3 & NS & NS & $* * *$ & $* * *$ & $* *$ & $* *$ \\
P $\times$ C & 3 & NS & NS & NS & NS & NS & NS \\
E $\times$ P $\times$ C & 3 & NS & NS & NS & $*$ & NS & NS \\
Replication (experiment) & 2 & NS & NS & $* * *$ & NS & $* *$ & $* *$ \\
CV $(\%)$ & & 10.1 & 15.7 & 10.4 & 11.8 & 19.0 & 32 \\
\hline
\end{tabular}

*, **, *** Significant at the $5 \%, 1 \%$, and $0.1 \%$ probability levels, respectively; NS = nonsignificant mean square at $P \leq 0.05$. 


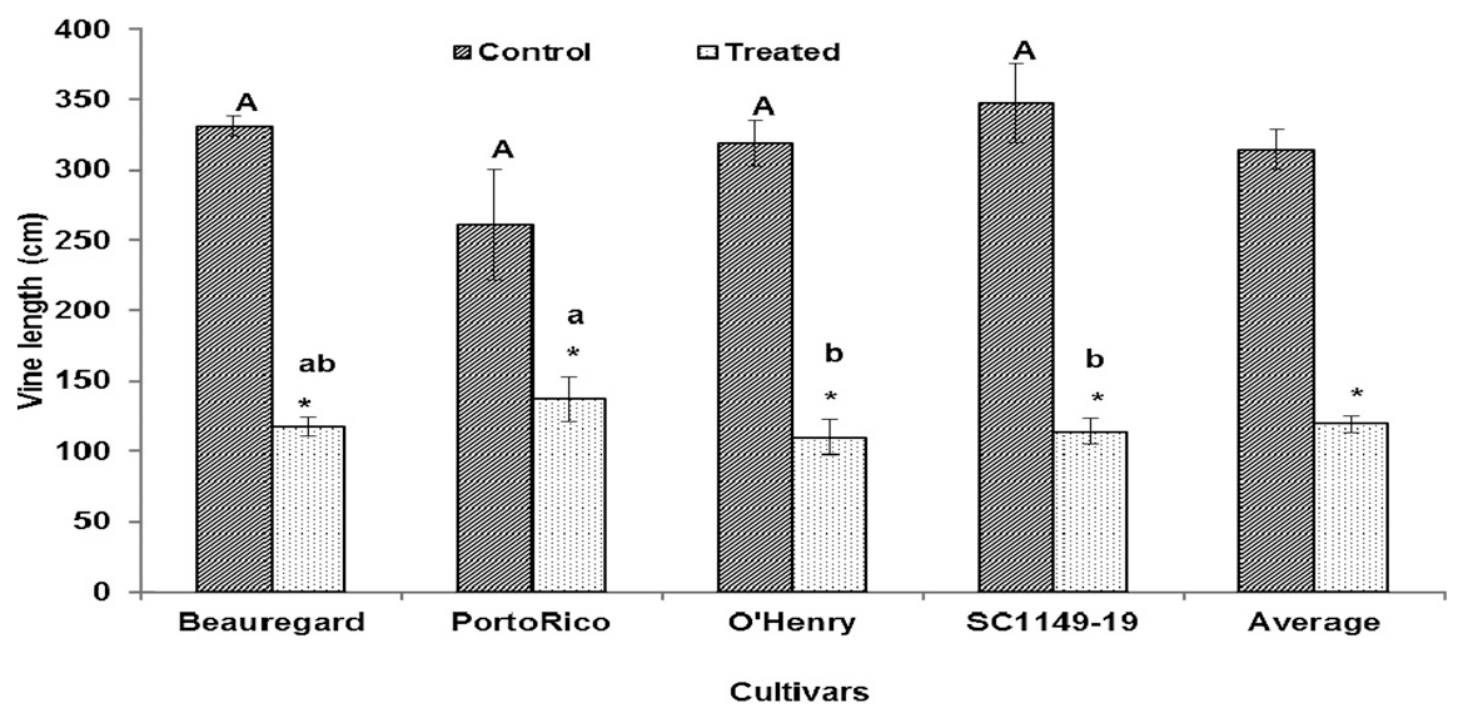

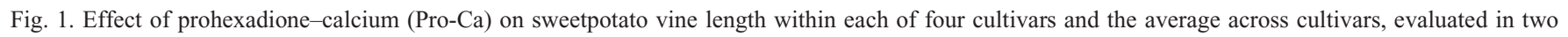
experiments, each with two replications. The asterisk indicates a significant difference $(P \leq 0.05)$ between treated and control; lower case letters compare cultivars within Pro-Ca-treated plots; bars carrying the same letter are not significantly different $(P \leq 0.05)$; upper case letters compare cultivars within control plots; bars carrying the same letter are not significantly different $(P \leq 0.05)$. Error bars represent SE of means $(P=0.05)$.

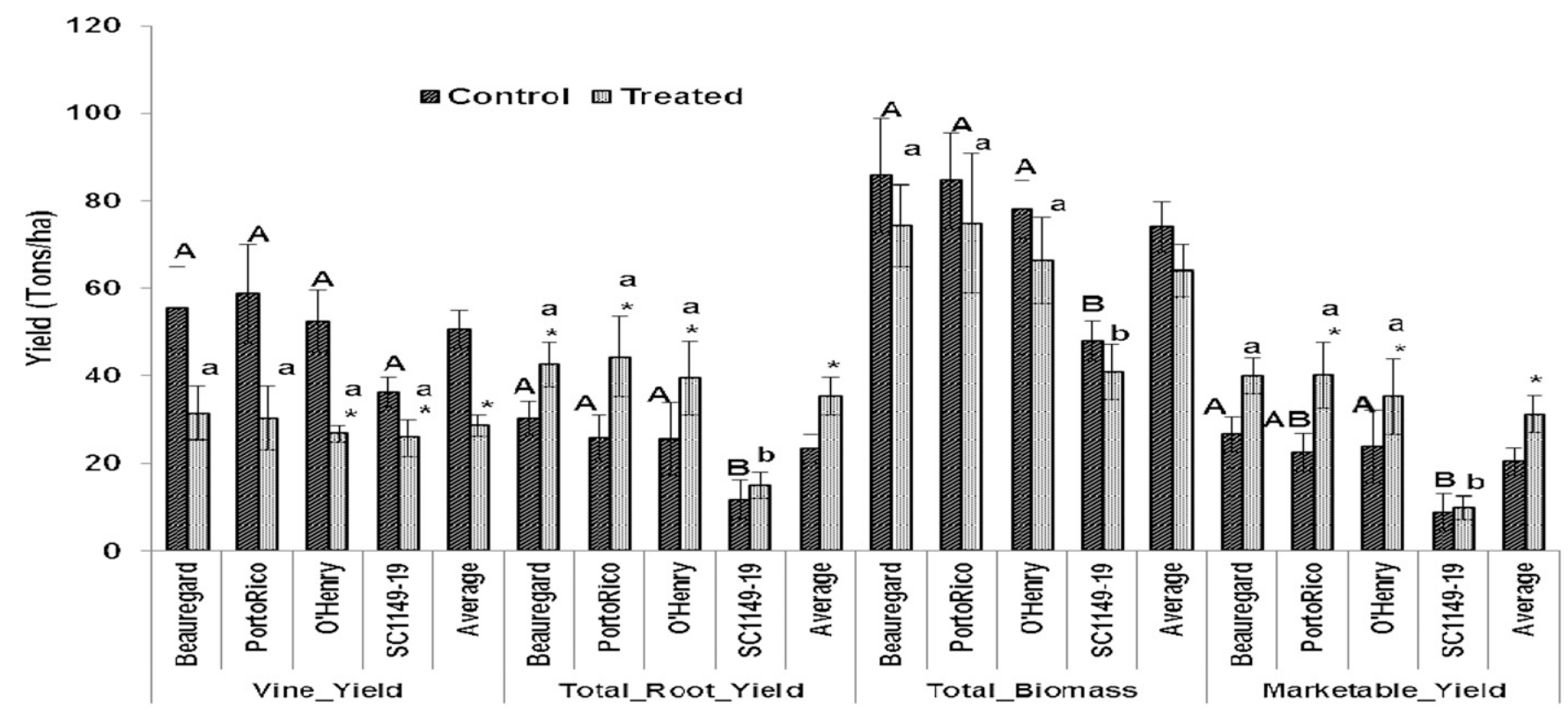

Fig. 2. Effect of Pro-Ca on sweetpotato vine yield, total root yield, total biomass, and marketable root yield within each of four cultivars and the average across cultivars (evaluated in two experiments with two replications each); the asterisk indicates a significant difference $(P \leq 0.05)$ between treated and control; lower case letters compare cultivars within Pro-Ca-treated plots for each trait; bars carrying the same letter are not significantly different $(P \leq 0.05)$; upper case letters compare cultivars within control plots for each trait; bars carrying the same letter are not significantly different $(P \leq 0.05)$. Error bars represent sE of means $(P=0.05)$.

associated with Pro-Ca application has been reported (Beam et al., 2002). However, the mechanism by which the yield enhancement occurs is still debatable (Beam et al., 2002). Although Pro-Ca-treated plants had significantly higher total root yield compared with the control plants in this study, there was no significant difference in total biomass between the treated and control plants, suggesting that Pro-Ca treatment affected the distribution of assimilates. Somasundaram and Santhosh Mithra (2008) reported that the photosynthates produced by sweetpotato are allocated to leaves, stems, and storage roots in proportion to their growth rates. Bouwkamp (1983) noted that sweetpotato may be source- or sink-limited depending on cultivar, environment, or canopy management. It has been reported that long days enhance vegetative growth and depress storage root bulking and short days result in less vegetative growth and enhance storage root bulking (McDavid and Alamu, 1980; Railton and Wareing, 1973). According to Lowe and Wilson (1974), the rates of growth of shoot and storage root can reflect the relative effectiveness of these systems as sinks for assimilates.

There was no significant difference in storage roots/plant between Pro-Ca-treated and control plants, suggesting that the yield difference observed between treated and control plants was mainly the result of larger storage roots in the treated plant. Lowe and Wilson (1974) indicated that higher storage root yield in sweetpotato is either a result of rapid bulking rate over a short period or slower bulking rate over a longer duration. It was not clear whether the larger storage roots observed in this study were a result of a short rapid bulking period or an extended slow bulking period in the treated plants.

In conclusion, plant growth inhibitors have found many applications in horticulture, mainly because they are able to induce 


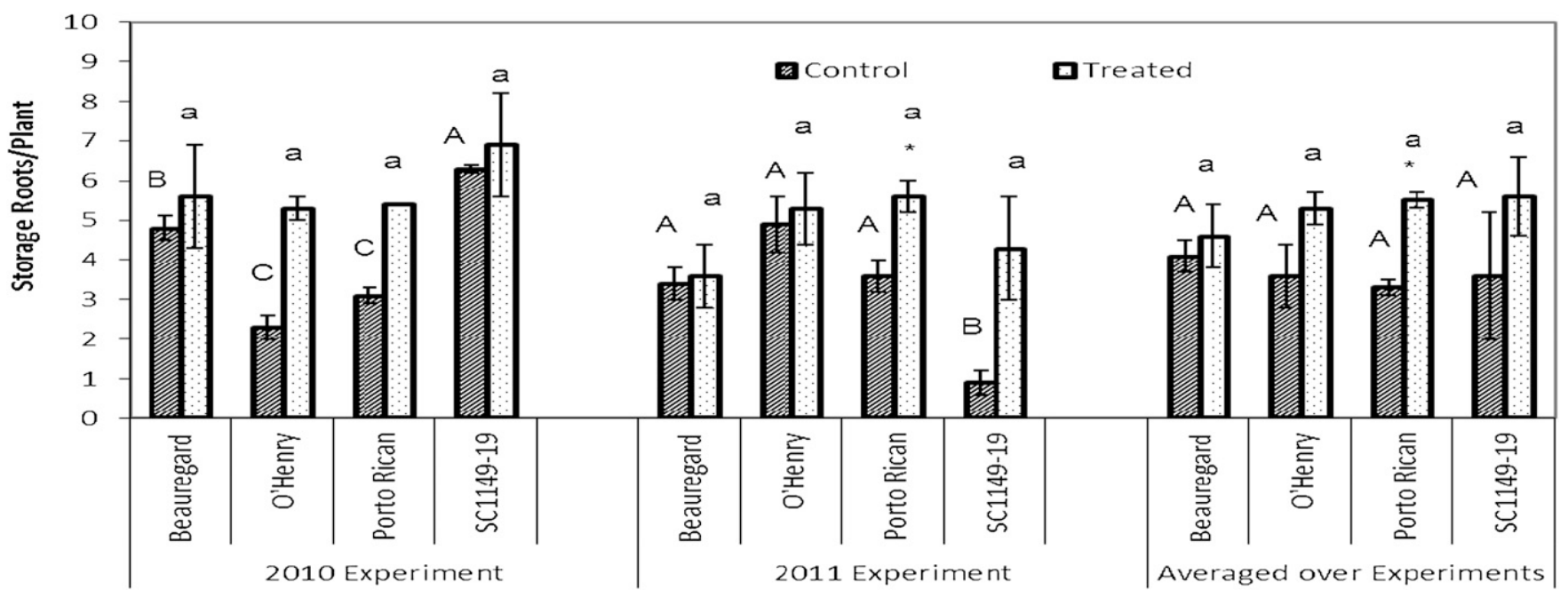

Fig. 3. Effect of Pro-Ca on sweetpotato storage root/plant among cultivars within experiment and among cultivars average across experiments (evaluated in two experiments with two replications each); the asterisk indicates a significant difference $(P \leq 0.05)$ between treated and control; lower case letters compare cultivars within Pro-Ca-treated plots; bars carrying the same letter are not significantly different $(P \leq 0.05)$; upper case letters compare cultivars within control plots; bars carrying the same letter are not significantly different $(P \leq 0.05)$. Error bars represent SE of means $(P=0.05)$.

dwarfism without affecting crop yield. Pro-Ca has been used to increase row visibility and harvest efficiency in peanuts, reduce pruning time in fruit trees, and increase fruit size. The findings from this study suggest that Pro-Ca may be a potential tool for manipulating "sinks," thus allowing more assimilate to be directed to growing storage roots in sweetpotato.

\section{Literature Cited}

All-about-sweet-potatoes.com. 2011. Sweet potato production \& consumption: Major global impact. $<$ http://www.All-About-Sweet-Potatoes.com>.

Beam, J.B., D.L. Jordan, A.C. York, T.G. Isleid, J.E. Bailey, T.E. McKemie, J.F. Spears, and P.D. Johnson. 2002. Influence of prohexadione Ca on pod yield and pod loss of peanut. Agron. J. 94:331-336.

Bouwkamp, J.C. 1983. Growth and partitioning in sweet potato. Ann. Trop. Res. 5:53-60.

CIP. 1999. Sweetpotato facts. 6 Apr. 2012. <http:// www.cipotato.org/sweetpotato/facts/swtfacts. pdf>.

Evans, J.R., J.A. Balles, B.A. Brinkman, V.E. Harris, J.D. Helm, K.B. Kirksey, T.E. McKemie, G.G. Thomas, and W. Rademacher. 1999. Prohexadione-Ca: Reduction in vegetative growth and pruning of apple trees. HortScience 34:483.

Gomez, K.A. and A.A. Gomez. 1984. Statistical procedure for agricultural research. 2nd Ed. John Wiley and Sons, New York, NY.

Hicklenton, P.R. 1990. Height control of pot and chrysanthemums with pre and post-plant treatments of daminozide and uniconazole. Can. J. Plant Sci. 70:925-930.

Jordan, D.L., J.B. Beam, P.D. Johnson, and J.F. Spears. 2001. Peanut response to Prohexadione calcium in three seeding rate-row pattern planting systems. Agron. J. 93:232-236.

Kofidis, G., A. Giannakoula, and I.F. Ilias. 2008. Growth, anatomy and chlorophyll fluorescence of coriander plants (Coriandrum sativum L.) treated with prohexadione calcium and Daminozide. Acta Biol. Cracov. Ser.; Bot. 50:55-62.
Lowe, S.B. and L.A. Wilson. 1974. Comparative analysis of tuber development in six sweet potato [Ipomoea batatas (L.) Lam] cultivars. Ann. Bot. (Lond.) 38:307-317.

McDavid, C.R. and S. Alamu. 1980. Effect of day length on the growth and development of whole plants and rooted leaves of sweet potato (Ipomoea batatas). Trop. Agr. 57:113119.

Miller, S.S. 2002. Prohexadione calcium controls vegetative shoot growth in apples. J. Tree Fruit Prod. 3:11-28.

Nakayama, L.M., K. Kobayashi, H.A. Kamiya, and Sakurai. 1992. Effect of plant growth regulators, prohexadione calcium (BX-112) on endogenous levels of gibberellins in rice. Plant Cell Physiol. 33:59-62.

Nakayama, M., H. Yamane, N. Murofushi, N. Takahashi, L.N. Mander, and H. Seto. 1991. Gibberellin biosynthetic pathway and the physiologically active gibberellin in the shoot of Cucumis sativus L. J. Plant Growth Regul. 10:115-119.

Nielson, L.W. and D.T. Pope. 1960. Resistance in sweetpotato to the internal cork virus. Plant Dis. 44:342-347.

Njiti, V.N., Q. Xia, L. Tyler, A. Tenner, L. Stewart, A. Tenner, and M. Gao. 2012. Effects of prohexadione calcium on sweet potato vegetative growth as influenced by cultivar and nitrogen. African J. Agr. Res. 7:2372-2379.

Norelli, J.L. and S.S. Miller. 2004. Effect of prohexadione calcium dose level on shoot growth and fire blight in young apple trees. Plant Dis. 88:1099-1106.

Rademacher, W. 2000. Growth retardants: Effects on gibberellin biosynthesis and other metabolic pathways. Annu. Rev. Plant Physiol. Plant Mol. Biol. 5:501-531.

Rademacher, W., K. Van Saarloos, J.A.G. Porte, F.R. Rorcades, Y. Senechal, C. Andreotti, F. Spinelli, E. Sabatini, and G. Costa. 2004. Impact of prohexadione-Ca on the vegetative and reproductive performance of apple and pear trees. Eur. J. Hort. Sci. 69:221-228.
Railton, I.D. and P.F. Wareing. 1973. Effects of day length on endogenous gibberellins in Solanum andigena $\mathrm{L}$. Changes in levels of free acidic gibberellin like substances. Physiol. Plant. 28:88-94.

Renter, M.G. and P.J.C. Stassen. 1998. The effect of growth inhibitors on vegetable growth, fruit size and fruit set in Hass Avocado trees: A preliminary report. South African Avocado Grower Assn. Yrbk. 21:54-57.

Rolston, L.H., C.A. Clark, J.M. Cannon, W.M. Randle, E.G. Riley, P.W. Wilson, and M.L. Robbins. 1987. 'Beauregard' sweetpotato. HortScience 22:1338-1339.

Sabatini, E., M. Noferini, G. Fiori, L.C. Grappadelli, and G. Costa. 2003. Prohexadione-Ca positively affects gas exchange and chlorophyll content of apple and pear trees. Eur. J. Hort. Sci. 69:123-128.

SAS Institute. 1985. SAS user's guide: Statistics. SAS Institute, Cary, NC.

Smith, M., J.J. Meintjes, G. Jacobs, P.J.C. Stassen, and K.I. Theron. 2005. Shoot growth control of pear trees (Pyrus communis) with prohexadione calcium. Sci. Hort. 106:515-529.

Smith, S.L. and M.E. Wright. 1994. A preharvest vine disposal machine for sweet potato. Appl. Eng. Agr. 10:321-326.

Smith, T.P. and A. Villordon. 2012. Improving sweetpotato production efficiency: Storage root initiation. 5 Oct. 2012. <http://www. lsuagcenter.com/NR/rdonlyres/E2C0CA2603DD-4FCC-B7EC-AC3968AE8DD9/85783/ pub3235AStoragerootinitiationLOWRES.pdf>. Somasundaram, K. and V.S. Santhosh Mithra. 2008 Madhuram: A simulation model for sweet potato growth. World J. Agr. Sci. 4:241-254.

USDA. 2005. United States standards for grades of sweetpotatoes. 17 Aug. 2012. <http://www. ams.usda.gov/AMSv1.0/getfile? $\mathrm{dDocName}=$ STELPRDC5050330>.

Williams, M.W. 1988. Cultural and chemical control of vegetative growth of deciduous fruit trees: Introduction to workshop. HortScience 175:121-126 